Jurnal Pembangunan Pendidikan: Fondasi dan Aplikasi

Volume 3, No 2, Desember 2015 (126-141)

Tersedia Online: http://journal.uny.ac.id/index.php/jppfa

\title{
NILAI-NILAI EDUKATIF LAGU-LAGU MINANG UNTUK MEMBANGUN KARAKTER PESERTA DIDIK
} (Analisis Hermeneutik)

\author{
${ }^{1)}$ Desyandri, ${ }^{2)}$ Achmad Dardiri, ${ }^{3)}$ Kun Setyaning Astuti \\ ${ }^{1)}$ Universitas Negeri Padang, ${ }^{2,3}$ niversitas Negeri Yogyakarta \\ ${ }^{1)}$ desyandri@yahoo.co.id, ${ }^{2)}$ achmaddardiri@uny.ac.id, ${ }^{3)}$ kunastuti@yahoo.com
}

\begin{abstract}
Abstrak
Penelitian ini bertujuan untuk mengungkap dan mengidentifikasikan nilai-nilai edukatif lagu-lagu Minang untuk membangun karakter peserta didik. Metode penelitian adalah penelitian konseptual (literatur review), teknik pengumpulan data menggunakan observasi berperan serta, wawancara, dokumentasi, dan catatan lapangan, sedangkan teknik analisis data menggunakan analisis hermeneutik. Hasil penelitian menunjukkan bahwa lagu Minangkabau dan Kampuang nan Jauah di Mato memiliki 9 (sembilan) nilai-nilai edukatif, yaitu: (1) Ketuhanan (syarak atau agamo), (2) kecintaan terhadap ranah Minang, (3) persaudaraan dan gotong-royong, (4) kesatuan dan kebersamaan, (5) musyawarah dan mufakat, (6) adil dan damai, (7) keteguhan hati, (8) waspada, dan 9) disiplin. Nilai-nilai edukatif lagu-lagu Minang tersebut dijadikan sebagai pedoman dalam mengarahkan pikiran, tindakan, dan perilaku peserta didik, sehingga dapat diwujudkan peserta didik yang beradat, beradab, berkarakter.
\end{abstract}

Kata kunci: nilai-nilai edukatif, adat Minangkabau, lagu Minang, pembangunan karakter

\author{
EDUCATIONAL VALUES OF MINANG SONGS \\ FOR STUDENTS CHARACTER BUILDING \\ (Hermeneutic Analysis) \\ ${ }^{1)}$ Desyandri, ${ }^{2)}$ Achmad Dardiri, ${ }^{3)}$ Kun Setyaning Astuti \\ ${ }^{1)}$ Universitas Negeri Padang, ${ }^{2,3}$ niversitas Negeri Yogyakarta \\ ${ }^{1)}$ desyandri@yahoo.co.id, ${ }^{2)}$ achmaddardiri@uny.ac.id, ${ }^{3)}$ kunastuti@yahoo.com
}

\begin{abstract}
This research aims to uncover and identify the educational values of Minang songs for student character building. The research method is a conceptual research (literature review), data collection techniques using participant observation, interviews, documentation, and field notes, while data analysis techniques using hermeneutic analysis. The results showed that Minangkabau and Kampuang nan Jauah di Mato songs has 9 (nine) educational values, namely: (1) belief (syarak or agamo), (2) love of the realm Minang, (3) fraternity and mutual assistance, (4) unity and togetherness, (5) deliberation and consensus, (6) fair and peaceful, (7) courage, (8) alert, and (9) discipline. Educational values of Minang songs are used as guidelines in directing thoughts, actions, and behavior of students, so it can be realized the students were well-mannered, cultured, and charactered.
\end{abstract}

Keywords: educational values, custom of Minangkabau, Minang songs, character building 


\section{PENDAHULUAN}

Adat Minangkabau sebagai bagian dari khazanah budaya memiliki keunikan tersendiri dan merupakan aset Provinsi Sumatera Barat. Adat Minangkabau bermanfaat bagi bangsa dan negara terutama bagi etnis Minang sendiri menuju masyarakat yang maju, beradat, berbudaya tinggi, dan berkarakter dalam mengisi pembangunan bangsa dalam wadah Negara Kesatuan Republik Indonesia (NKRI).

Adat Minangkabau dirancang berdasarkan akal-budi (perpaduan antara pikiran dan perasaan untuk menimbang baik dan buruk mengacu pada alam takambang jadi guru, raso jo pareso (rasa/karsa dengan periksa/kontrol) yang menurut alua jo patuik (alur dan patut) akan melahirkan tindakan (sikap dan perilaku) yang baik dengan mempertimbangkan perasaan malu dan sopan, agar memunculkan kearifan pengetahuan dan berperilaku sebagai manusia dalam kehidupan sosial yang beradab (Zainuddin, 2010, p. 106). Adat Minangkabau memberikan acuan atau pedoman nilai-nilai yang bersumberkan dari akal-budi dalam menjalani kehidupan, sehingga melahirkan tindakan dan perilaku masyarakat yang mencerminkan karakter khas orang Minangkabau.

Pembahasan tentang nilai-nilai dalam adat Minangkabau memiliki cakupan yang sangat luas. Untuk itu, dikemukakan tiga nilai-nilai utama yang dapat dijadikan sebagai acuan dalam melahirkan perilaku dan karakter orang Minang. Pertama, nilai-nilai dasar (falsafah), yakni: Adat Basandi Syarak - Syarak Basandi Kitabullah (ABS-SBK) dan Alam Takambang Jadi Guru. Inti sari nilai-nilai dasar ABS-SBK tersebut menjelaskan bahwa adat Minangkabau bersendikan syari'at dan syari'at bersendikan kitabullah (Alquran). Adat Minangkabau menyandarkan diri pada ajaran agama Allah yakni Islam yang memegang teguh Alquran dan Hadis Rasulullah. Nilai-nilai dasar tersebut dijadikan sebagai pedoman dasar untuk mewujudkan masyarakat Minangkabau yang aman dan makmur secara lahir dan batin, berbudi luhur, berakhlak mulia, dan diridai Allah Swt, sedangkan Alam Takambang Jadi Guru, menurut Hakimy (1987, p. 2) bahwa alam yang terkembang sebagai ciptaan Allah dapat dipelajari dengan seksama dan merupakan sumber pengetahuan, pada ahirnya dapat mengarahkan dan memberikan pedoman bagi masyarakat dalam melahirkan tindakan atau perilaku yang beradat, beradab, dan berkarakter.

Kedua, garis keturunan menurut ibu (matrilineal). Sistem kekerabatan matrilineal secara tidak langsung memberikan apresiasi yang tinggi terhadap kaum perempuan/ibu (bundo kanduang) baik di dalam struktur adat maupun dalam kehidupan bermasyarakat, sehingga berpengaruh terhadap pelahiran nilainilai yang mengutamakan kaum ibu tanpa menghilangkan peranan bapak (laki-laki.

Ketiga, kebiasaan atau tradisi merantau. Merantau merupakan kebiasaan atau tradisi yang telah dilakukan masyarakat Minang sejak dahulu kala. Merantau bagi orang Minang, salah satunya merupakan lambang harga diri di tengah-tengah masyarakat, seperti kata pepatah Minang, "karatau madang di hulu, babuah babungo balun, marantau bujang daulu, di rumah paguno balun". Generasi muda Minang akan berguna di kampung apabila mereka sudah merantau, mencari ilmu di negeri orang, mencari hidup dan menjalani kehidupan yang susah-senang di rantau orang. Dengan demikian, dapat dikemukakan bahwa kebiasaan atau tradisi merantau bagi orang Minang memberikan cerminan nilai-nilai keuletan, ketangguhan, keteguhan hati, kerja keras, dan keberanian.

Ketiga nilai-nilai utama adat Minangkabau yang dikemukakan sebelumnya, membuktikan bahwa secara ideal adat Minangkabau telah memberikan bekal nilai-nilai bagi orang Minang dalam mengarungi kehidupan sehari-hari, baik kehidupan individu maupun kehidupan bermasyarakat, serta dijadikan sebagai sarana edukatif bagi untuk mewujudkan tujuan adat Minangkabau, yakni membentuk orang Minang yang berbudi luhur, berbudaya, dan beradab.

Pewarisan nilai-nilai adat Minangkabau telah dilakukan secara turun-temurun dengan berbagai cara. Dalam masyarakat Minangkabau, salah satu cara yang digunakan adalah melalui seni pertunjukan atau kesenian Minang, seperti yang dikemukakan Amir (2011, p. 76) bahwa adat-istiadat merupakan aneka kelaziman dalam suatu nagari. Kelaziman ini pada umumnya menyangkut pengejawantahan unjuk rasa seni budaya masyarakat, seperti acara-acara keramaian anak nagari (generasi muda), seperti pertunjukan randai, 
saluang, aneka tari-tarian, dan aneka ragam kesenian.

Salah satu di antara jenis kesenian yang ada di Minangkabau adalah lagu-lagu Minang yang mengandung nilai-nilai dan menggambarkan kondisi realitas yang terjadi di masyarakat. Nilai-nilai tersebut dijadikan sebagai pedoman dalam melahirkan tindakan dan perilaku yang mencerminkan karakter orang Minang. Barendregt (2002, p. 416) mengatakan bahwa:

Minang songs, provides one of the avenues through which identification as Minangkabau is experienced, defined, and consumed internally. It constructs a Minangkabau sensibility "by depicting a recognizable landscape through the use of metaphors" related to migration and the homeland.

Lagu-lagu Minang yang mengidentifikasikan budaya Minangkabau dikonsumsi secara internal dapat membangun dan menggambarkan perasaan tentang keindahan alam yang dikenali melalui penggunaan metafora terkait dengan ranah Minang dan kebiasaan atau tradisi merantau. "The attachment goes beyond this landscape to "a community sharing the same moral values" (ibid., p. 417). Lagu-lagu Minang sekedar menceritakan tentang kerinduan terhadap alam Minangkabau, bahkan merupakan upaya masyarakat untuk berbagi nilai-nilai moral.

Hajizar (2012) yang menyatakan bahwa lagu-lagu Minang berangkat dari resepsi nilai-nilai sosial masyarakat. Dengan demikian, lagu-lagu Minang dapat digambarkan sebagai sebuah keintiman atau kedekatan dengan budaya Minangkabau, seperti yang dikemukakan Fraser (2011), "Minang songs is a form of cultural intimacy, one that allows the Minangkabau to recognize themselves within the nation as distinct from its other constituents".

Lagu-lagu Minang memiliki dua unsur pokok. Pertama, unsur musik yang khas Minangkabau, seperti beragam alat musik yang khas Minang, seperti talempong, gandang, bansi, saluang, rabab, dan kecapi. Irama dan melodi lagu-lagu Minang memiliki nuansa unik, yakni memiliki cengkok (gariniak) Minang, seperti yang diungkapkan Budiman (2011) bahwa lagu-lagu Minang disampaikan dalam alunan melodi yang kental dengan keunikan "gariniak" atau cengkok Minang. Kedua, unsur lirik lagu-lagu Minang memiliki lirik yang berbentuk sajak dan pantun, seperti yang diungkapkan Darwis (2005) bahwa pantun pernah memegang peranan penting dalam kesenian Minangkabau. Orang Minang sering mengungkapkan perasaannya dengan pantun, berdialog, bahkan bersahutan kata.

Budiman (2011) mengemukakan bahwa lirik memberikan indikasi bahwa "Pusako urang Minang tu, iyolah kato" artinya pusaka orang Minang itu adalah kata. "Kato bakieh (kata sindiran), kato bamukasuik (kata yang ditujukan untuk...), tanyo baalamat (pertanyaan yang jelas), manggado manghadang tampuak (hal-hal yang tepat sasaran), balaia manghadang pulau (upaya untuk menyelesaikan petualangan)". Setiap kata memiliki maksud dan tujuan tertentu. Di samping itu, lirik lau-lagu Minang memiliki nilai-nilai kearifan yang santun dan menuntun.

Selain kekhasan musik dan nilai-nilai yang terkandung dalam lirik lagu-lagu, lagulagu Minang terbukti sangat dekat dengan pendengar atau masyarakat pendukungnya. Hal ini terlihat dari kepopuleran lagu-lagu Minang yang tidak hanya di wilayah Minangkabau, akan tetapi beberapa lagu tersebut telah dikenal secara nasional hingga ke manca negara dan bahkan beberapa lagu Minang tergolong lagu-lagu yang melegenda. Kepopuleran dan kedekatan lagu-lagu Minang dengan masyarakat pendukung menandakan bahwa pesan nilai-nilai yang terkandung dalam lagulagu Minang diterima dan hidup di hati masyarakat Minangkabau. Musik dan lirik lagulagu Minang mengedukasi pendengar atau pendukungnya untuk selalu mengikuti nilainilai adat Minangkabau dan memperlihatkan perilaku yang berbudi luhur, bertutur kata yang sopan dan santun, cinta kampung halaman, dan memberikan kesadaran untuk selalu menjunjung tinggi budaya sendiri.

Nilai-nilai utama adat Minangkabau dan nilai-nilai yang terkandung dalam lagulagu Minang yang dipaparkan sebelumnya, merupakan produk lampau yang menjadi warisan budaya. Nilai-nilai tersebut tetap dipahami, diamalkan, dan dibela oleh masyarakat terdahulu sebagai pedoman dalam melahirkan tindakan atau perilaku yang mencerminkan watak/karakter orang Minang, serta dijadikan sarana untuk mengenalkan adat Minangkabau kepada masyarakat. Mengingat 
keberhargaan dan pentingnya nilai-nilai tersebut, seharusnya tetap dimanifestasikan secara teguh oleh generasi berikutnya. Untuk itu, diperlukan upaya pelestarian dan pembudayaan. Salah satu upaya yang dapat dilakukan dalam melestarikan dan membudayakan kembali nilai-nilai edukatif yang terkandung dalam adat Minangkabau dan lagu-lagu Minang adalah dengan menyinergikan pendidikan dan kebudayaan.

Pendidikan dan kebudayaan merupakan dua hal yang tidak dapat dipisahkan dan saling terkait satu sama lain. Pandangan ini memerlukan tindak lanjut untuk mensinergikan pendidikan dan kebudayaan. Pendidikan memiliki peranan penting untuk menanamkan nilai-nilai kebudayaan, diantaranya nilai-nilai adat Minangkabau dan lagu-lagu Minang.

Dewantara (Suratman, 1987, p. 12) mengatakan bahwa pendidikan ialah usaha kebudayaan yang bermaksud memberi bimbingan dalam hidup tumbuhnya jiwa raga peserta didik, agar dalam kodrat pribadi dan pengaruh lingkungan dapat memperoleh kemajuan lahir batin menuju ke arah adab kemanusiaan. Dalam kaitan ini, Tilaar $(2010$, p. 190) mengemukakan bahwa ahli antropologi maupun ahli pendidikan sepakat bahwa pendidikan tidak terjadi di dalam vakum tetapi terlaksana di dalam suatu kehidupan yang berbudaya yang dimiliki oleh setiap masyarakat.

Pembudayaan nilai-nilai yang terkandung dalam budaya, salah satunya nilai-nilai edukatif lagu-lagu Minang bertujuan untuk membangun karakter peserta didik, baik ketika berada di lingkungan sekolah, maupun berada di lingkungan masyarakat dan budaya. Di Indonesia, Bapak Pendidikan Dewantara (1977, p. 24) telah jauh berpikir tentang karakter, beliau mengemukakan bahwa mengasah kecerdasan budi sungguh baik, karena dapat membangun budi pekerti yang baik dan kokoh, hingga dapat mewujudkan kepribadian (persoonlijkhheid) dan karakter (jiwa yang berasas hukum kebatinan). Jika hal itu terwujud, senantiasa dapat mengalahkan nafsu dan tabiat-tabiat negatif (bengis, murka, pemarah, kikir, keras, dan lain-lain) seseorang.

Pandangan lain dikemukakan Lickona (1991, p. 53) bahwa karakter terdiri atas nilainilai operatif, nilai-nilai dalam tindakan. Kemajuan karakter sebagai sebuah nilai menuju kebajikan, karakter batin dapat diandalkan untuk merespon situasi dengan cara yang baik secara moral. Karakter memiliki tiga bagian yang saling berhubungan, yaitu pengetahuan moral, perasaan moral, dan perilaku moral. Karakter yang baik terdiri dari mengenal yang baik, menginginkan yang baik, dan melakukan yang baik- pembiasaan dalam pikiran, hati, dan tindakan.

Pandangan senada dikemukakan Berkowitz (2002, p. 48), bahwa karakter merupakan seperangkat karakteristik psikologis individu yang mempengaruhi kemampuan orang dan kecenderungan berfungsi secara moral. Sederhananya, karakter terdiri dari karakteristik yang menyebabkan seseorang untuk melakukan hal yang benar atau tidak.

Pandangan-pandangan tentang konsep dan definisi karakter yang telah dikemukakan sebelumnya, menjelaskan bahwa karakter merupakan upaya secara optimal dalam rangka menyeimbangkan kemampuan inteligensi dan karakter dalam mencapai tujuan pendidikan. Upaya tersebut dilakukan dengan menumbuhkembangkan sifat-sifat, budi pekerti (tindakan dan perilaku) terpuji, dan melahirkan warga masyarakat dan bangsa yang berkarakter. Dengan upaya tersebut, pendidikan dapat melahirkan peserta didik yang memiliki pengetahuan luas dan berkarakter, baik ketika berada di lingkungan sekolah maupun dalam lingkungan keluarga/masyarakat.

Pembangunan karakter peserta didik tidak terlepas upaya kolektif sekolah dan keluarga/masyarakat sebagai bagian integral dalam pendidikan sangat berperan penting membantu proses transformasi nilai-nilai budaya dalam rangka membangun karakter peserta didik. Upaya kolektif tersebut mengacu pada nilai-nilai edukatif yang terkandung dalam lirik lagu-lagu Minang sebagai aktualisasi nilai-nilai adat Minangkabau, sehingga nilainilai dijadikan pedoman dalam melahirkan perilaku untuk membangun karakter peserta didik.

Sekolah merupakan wadah yang dianggap sebagai instrumen pembaharuan dan perubahan. Sekolah dipandang mereproduksi atau menyampaikan budaya dari generasi yang satu ke generasi yang lain dengan berbagai cara. Konsepsi umum mengenai apa yang disampaikan di sekolah adalah muatan kurikulum-sekumpulan kecakapan akademik yang disepakati untuk disampaikan oleh pihak sekolah. 
Sekolah dan sivitasnya sebagai wadah yang membantu tumbuhkembangnya nilainilai adat Minangkabau yang diaktualkan melalui lagu-lagu Minang dapat dijadikan sebagai pedoman dalam melahirkan perilaku dan sarana untuk membangun karakter peserta didik merupakan upaya serius harus dilakukan secara berkelanjutan. Sehingga dapat memberikan dukungan dan motivasi kepada peserta didik untuk memahami, menginternalisasi, dan melestarikan nilai-nilai adat atau budaya Minangkabau.

Pembangunan karakter peserta didik tidak hanya dilakukan di sekolah saja, tetapi membutuhkan peranan keluarga/masyarakat. Arthur \& Baely (2002, p. 30) mengemukakan bahwa masyarakat dipengaruhi oleh beragam konsekuensi, baik positif maupun negatif dan memiliki hak dan kewajiban untuk terlibat secara aktif dalam membesarkan anak.

Melihat kondisi ideal pendidikan sebagai upaya normatif dalam perberdayaan dan pembudayaan khususnya di wilayah Minangkabau atau Sumatera Barat pada kondisi sekarang, secara umum masih menyisakan berbagai permasalahan yang mengarah pada hilangnya jati diri masyarakat Minangkabau atau tercerabutnya orang Minang dari budayanya sendiri, seperti yang dikemukakan Naim (2003) bahwa permasalahan besar yang dihadapi masyarakat Minangkabau adalah hilangnya hal yang paling berharga dari diri mereka, yaitu jati diri. Jati diri yang dimaksudkan adalah nilai-nilai adat Minangkabau yang menjadi ajaran dan tujuan adat Minangkabau.

Permasalahan tersebut diperparah lagi dengan bergulirnya arus globalisasi yang secara langsung atau tidak langsung telah membawa wajah baru dalam penampilan adat budaya (Sairin, 2004). Masyarakat Minangkabau yang semakin kuat berinteraksi dengan masyarakat dunia pada saat sekarang tidak terhindarkan menyerap berbagai nilai budaya dari ranah budaya universal (Amir, 2007). Masyarakat Minangkabau mengalami kegoncangan budaya yang menyeret generasi muda untuk mencari jalan hidupnya sendiri-sendiri dengan kontrol budaya yang lemah (Sairin, 2004). Reno (2012) yang dilansir Harian Pagi Padang Ekspres mengemukakan bahwa pengaruh teknologi informasi mengalahkan nilai-nilai adat Minangkabau. Dunia IPTEKS telah mendekatkan manusia pada sekularisme, pluralisme, liberalisme, matrialisme dan hedo- nisme, yang membawa umat manusia kian jauh dari nilai-nilai agama dan norma-norma kehidupan masyarakat Minangkabau.

Realitas yang terjadi di lapangan menunjukkan bahwa secara kuantitas seiring dengan perkembangan zaman memperlihatkan kondisi perilaku peserta didik dan masyarakat yang semakin mengkhawatirkan, seperti berita yang dirilis Harian Padang Ekspres 29 April 2013 bahwa satu per satu peserta didik di Kota padang tersandung kasus hukum, baik yang disebabkan tawuran antar pelajar, pencurian, maupun kasus kepemilikian narkoba. Selain itu, Riadi (2014) dilansir Republika memberitakan bahwa hari kelulusan diwarnai dengan tawuran pelajar di Ruang Terbuka Hijau (RTH) Imam Bonjol Kota Padang. Fakta ini menggambarkan bahwa proses pendidikan belum berjalan dengan optimal dan menjauh dari nilai-nilai adat Minangkabau.

Dua mata pelajaran dalam pendidikan yang berkaitan langsung dengan nilai-nilai adat Minangkabau dan lagu-lagu Minang, adalah Budaya Alam Minangkabau (BAM) dan Pendidikan Seni Musik. Secara umum pembelajaran yang dilakukan belum optimal. Pertama, pelajaran BAM yang dilakukan masih sebatas mengenalkan pepatah dan petatahpetitih adat Minangkabau. Belum dilanjutkan dengan pemahaman dan pengaktualan nilainilai tersebut dalam melahirkan perilaku peserta didik (Sayuti, 2012)

Kedua, realita pendidikan dan pembelajaran pendidikan seni musik di sekolah, khususnya di Kota Padang juga ditengarai belum optimal. Proses pendidikan lebih berorientasi pada penguasaan kemampuan intelektual semata, mengabaikan proses pelestarian nilai-nilai adat Minangkabau dan nilainilai edukatif yang terkandung dalam lagulagu Minang, sehingga pendidikan hanya dijadikan sebagai alat untuk memperkaya pengetahuan tetapi miskin nilai-nilai. Tilaar (2010, p. 218) mengemukakan bahwa intelektualisme yang telah menjadi ciri pendidikan nasional telah mengasingkan budaya dan apresiasi budaya dalam pendidikan nasional. Bukan berarti bahwa kognisi tidak diperlukan dalam pengembangan kepribadian manusia.

Pandangan Tilaar terlihat dalam realita pembelajaran pendidikan seni. Pembelajaran difungsikan sebagai hiburan semata, pemberian materi dalam bentuk hafalan musik/ lagu-lagu Minang, mengekplorasi kandungan 
nilai-nilai edukatif secara garis besar tanpa dilanjutkan dengan pengimplementasian dan pembudayaan nilai-nilai tersebut dalam kehidupan peserta didik. Bahkan sekolah-sekolah di Kota Padang terlihat mulai meninggalkan lagu-lagu Minang, sehingga nilai-nilai edukatif yang terkandung dalam lagu-lagu tersebut tidak lagi difungsikan sebagaimana mestinya. Hal ini dapat dibuktikan dengan sedikitnya lagu-lagu Minang yang dibelajarkan di sekolah dan kebanyakan peserta didik kurang mengetahui lagu-lagu Minang. Seharusnya pendidikan seni musik dapat mengembangkan rasa keindahan, kreativitas, dan kepribadian, serta menjadikan peserta didik lebih produktif dan berbudaya (Astuti, 2010: p. 5).

Kondisi tersebut tidak dapat dibiarkan begitu saja, diperlukan upaya penelitian dan sekaligus menjadi salah satu alternatif dalam mencarikan solusi terhadap memudarnya nilai-nilai edukatif lirik lagu-lagu Minang sebagai sarana untuk membangun karakter peserta didik. Permasalahan ini harus mendapat penanganan segera dan menjadikan penelitian ini mendesak (urgency) untuk dilakukan.

Penguasaan kemampuan intelektual yang mengabaikan penanaman nilai-nilai karakter penyebab tumbuhnya tindakan dan perilaku negatif. Hal itu memberikan indikasi bahwa kemampuan intelektual saja tidaklah cukup dalam aktivitas pendidikan, untuk menggabungkan kemampuan intelektual dengan pembangunan karakter yang didasarkan pada nilai-nilai edukatif lirik lagu-lagu Minang sebagai aktualisasi nilai-nilai adat atau budaya Minangkabau. Berikut dipaparkan pandangan-pandangan tentang pembangunan karakter, sehingga melahirkan perilaku yang beradab dan berbudaya.

Dunia internasional telah lama mengungkapkan akan pentingnya karakter. Jakoubek (2005, p. 25) mengutip pendapat Martin Luther King Jr., speech at Morehouse College 1948 yang mengemukakan bahwa:

We must remember that intelligence is not enough. Intelligence plus character, that is the goal of true education. The complete education gives one not only power of concentration, but worthy objectives upon which to concentrate. The broad education will, therefore, transmit to one not only the accumulated knowledge of the race but also the accumulated experience of social living.
Dominasi kemampuan inteligensi belum menghasilkan proses pendidikan yang optimal. Perpaduan antara inteligensi dan karakter, itulah tujuan pendidikan sebenarnya. Pendidikan yang optimal, bukan hanya memberikan kemampuan untuk berkonsentrasi, tetapi memberikan tujuan yang layak sebagai dasar konsentrasi. Pendidikan yang luas seharusnya sebuah proses transmisi yang meliputi akumulasi pengetahuan dan akumulasi pengalaman hidup sosial. Dengan demikian dapat dimaknai bahwa pendidikan yang optimal dapat dilakukan dengan memadukan kemampuan inteligensi dan karakter serta melakukan proses di samping proses transmisi dalam memberikan akumulasi pengetahuan dan akumulasi pengalaman hidup sosial.

\section{METODE PENELITIAN}

Penelitian ini merupakan penelitian konseptual (literatur review) yang bertujuan untuk mengungkap nilai-nilai yang terkandung dalam lagu-lagu Minang dengan menggunakan analisis hermeneutik dalam membangun karakter peserta didik. Fithri (2013, p. 50) mengutip pendapat Ricoeur yang mengemukakan bahwa hermeneutik adalah teori tentang bekerjanya pemahaman dalam hubungannya dengan interpretasi teks. Wachid (2006, p. 214) mengutip pendapat Recoeur dan Betti yang mengemukakan bahwa hermeneutik adalah kajian untuk menyingkap makna objektif dari teks-teks yang memiliki jarak ruang dan waktu dari pembaca.

Analisis mengacu pada unsur-unsur dan penerapan teori hermeneutik Ricoeur (Fithri, 2003, pp. 64-74) yang dikombinasikan dengan analisis multidisipliner (mengaitkan dengan disiplin ilmu bahasa, musik, psikologi, sosiokultural, dan pendidikan). Pertama, objektivikasi struktur teks. Lagu-lagu Minang yang telah dipilih, ditafsirkan secara objektif oleh peneliti, sehingga terjadinya proses dialog antara peneliti dengan teks/lirik lagu-lagu Minang.

Kedua, distansiasi (perjarakan). Peneliti berupaya untuk menginterpretasikan lagulagu Minang dan sekaligus menjaga agar otonomi lirik tetap terjaga dengan cara distansiasi makna dari peristiwa, yaitu terjadinya dialektika antara wacana dan peristiwa, distansiasi makna teks dengan maksud pengarang, kondisi awal teks dengan dimensi sosio kultural- 
nya tidak diperlukan mengingat teks terbuka untuk siapapun, dan distansiasi audiens. Teks membebaskan diri dari audiens awal dan selanjutnya membuka diri bagi siapapun.

Ketiga, apropriasi. Apropriasi bertujuan untuk mengaktualkan makna teks bagi pembaca terkini. Teks/lirik lagu-lagu Minang ditafsirkan berdasarkan penafsir dan pembaca pada kondisi saat sekarang. Peneliti berupaya memberikan makna baru sesuai dengan otonomi lirik lagu-lagu Minang.

Keempat, analogi permainan. Penerapan analogi permainan membawa penafsir untuk memperkaya teks yang ditafsirkan. Lagu-lagu Minang dapat ditafsirkan menjadi lebih lentur, sehingga memungkinkan kreativitas penafsir untuk menemukan maknamakna baru.

Informan dalam penelitian adalah aktor-aktor yang terlibat pada latar penelitian yang dimanfaatkan untuk memberikan informasi tentang kandungan nilai-nilai edukatif lagu-lagu Minang, yaitu pakar musik/lagulagu Minang, dan pakar budaya Minangkabau, sedangkan objek penelitian ini adalah 2 (dua buah) lagu Minang yang sering dibelajarkan di lingkungan Pendidikan Dasar Kota Padang, yaitu lagu Minangkabau dan Kampuang nan Jauah di Mato.

\section{HASIL DAN PEMBAHASAN}

Lagu Minangkabau dan Kampuang nan Jauah di Mato merupakan lagu terkenal dan sarat nilai-nilai edukatif. Berikut dilakukan pembahasan terhadap kedua lagu tesebut.

\section{Aspek Kebahasaan}

Aspek kebahasaan lagu Minangkabau, ciptaan NN (No Name) terdiri dari dua bait. Bait pertama terdiri dari empat kalimat lagu. Kalimat pertama Minangkabau tanah nan den cinto. Kalimat pertama tersebut terdiri dari empat kata, yakni Minangkabau, tanah, den, cinto. Secara leksikal atau dalam arti kamus dapat diterjemahkan bahwa kata "Minangkabau" merupakan sebuah tempat atau lokasi yang menggunakan aturan dan tatanan adat budaya di Minang. Arti kata "tanah" dapat diterjemahkan sebagai sebuah kampung halaman atau ranah, tempat tinggal, tempat seseorang (orang Minang) lahir, tumbuh, dan berkembang. Kata "den" dapat diterjemahkan sebagai sebutan diri sendiri bagi orang Minang. Sedangkan kata "cinto" berkaitan erat dengan unsur psikologis dan dapat diterjemahkan sebagai ungkapan perasaan suka, senang, rindu, dan cinta.

Kalimat di atas dapat ditafsirkan bahwa setiap orang Minangkabau sangat mencintai kampung halamannya. Dengan demikian orang-orang Minangkabau memiliki nilai-nilai kecintaan yang tinggi terhadap kampung halamannya sendiri, seperti kata pepatah, "Hujan ameh di nagari urang, hujan batu di nagari awak, rancak juo di nagari awak". Walaupun di negeri orang banyak menjanjikan kehidupan dan rezeki yang lebih baik dibandingkan dengan kondisi perekonomian di negeri sendiri, orang Minang tetap teguh dan mencintai kampung halamannya sendiri.

Kalimat kedua menyatakan bahwa pusako bundo dahulunyo". Kalimat kedua terdiri dari tiga kata, yakni pusako, bundo, dan dahulunyo. Kata "pusako" dapat diartikan sebagai sebuah warisan secara turun temurun. Kata bundo memiliki banyak arti, yakni: (1) ibu pertiwi atau tanah kelahiran, dan (2) panggilan khusus untuk orang tua perempuan (ibu), selain itu kata bundo memiliki arti yang sangat berpengaruh di Minangkabau, karena melambangkan bahwa garis keturunan atau warisan turun-temurun yang berlaku di Minangkabau didasarkan pada garis keturunan ibu. Kata dahulunyo menyangkut tentang ukuran waktu yang sudah berlangsung lama atau dengan kata lain sudah ada dari zaman nenek moyang.

Kalimat kedua dapat ditafsirkan bahwa Minangkabau sebagai sebuah aturan atau norma adat dan juga sebagai tanah tempat lahir, tumbuh, dan berkembangnya orang Minang merupakan warisan yang diturunkan melalui garis keturunan ibu (matrilineal) yang sudah ada semenjak zaman nenek moyang. Kalimat kedua mengadung nilai-nilai keberlangsungan atau keberlanjutan sebuah aturan adat atau budaya Minangkabau, sehingga nilai-nilai itu diharapkan dapat tumbuh dan berkembang pada zaman sekarang ini.

Kalimat ketiga menyatakan bahwa: rumah gadang nan sambilan ruang. Kalimat ketiga secara garis besar terdiri dari dua kelompok kata, yakni: rumah gadang dan sembilan ruang. Kelompok kata "rumah gadang" dapat diartikan sebagai sebuah rumah khas atau rumah adat orang Minangkabau. Rumah 
gadang yang luas dan memiliki sembilan ruang.

Kalimat keempat menyatakan bahwa: rangkiang baririk di halamannyo. Kalimat keempat terdiri dari tiga kata, yakni rangkiang, baririk, dan kata di halamannyo. Kata rangkiang dapat diartikan sebagai lumbung padi. Orang Minangkabau memiliki kebiasaan menyediakan sebuah tempat untuk menyimpan dan mengamankan hasil panen padi mereka. Kata baririk di halamannyo dapat diartikan bahwa di setiap rumah gadang memiliki beberapa tempat penyimpanan atau lumbung padi sebagai bekal bagi warga yang mendiami rumah gadang.

Kalimat keempat dapat ditafsirkan bahwa selain tinggal di rumah gadang, orang Minang memiliki kebiasaan untuk menabung atau menyimpan hasil panen padi atau dengan kata lain lumbung dapat difungsikan sebagai tempat persediaan makanan bagi penghuni rumah gadang dan keperluan makanan untuk pesta adat. Hasil panen yang terdapat dalam lumbung tersebut dapat digunakan sewaktuwaktu.

Keempat kalimat lagu pada bait pertama lagu Minangkabau, secara keseluruhan dapat ditafsirkan bahwa Minangkabau, baik sebagai sebuah tatanan adat maupun tempat lahir, tumbuh, dan berkembangnya orang Minang merupakan: (1) kampung halaman yang sangat dicintai baik bagi orang Minang yang berada di ranah Minang, maupun orang Minang yang berada di perantauan, (2) warisan seorang bundo (ibu) dari zaman nenek moyang dahulunya, (3) rumah tempat tinggal yang khas dan dikenal dengan nama rumah gadang yang memiliki sembilan ruang, dan (4) tempat persediaan makanan untuk keperluan makanan pengisi rumah gadang dan untuk keperluan upacara adat.

Bait kedua terdiri dari dua kalimat, yakni "Jikok den kana hati den taibo, tabayang-bayang di ruang mato". Kalimat tersebut dapat diartikan bahwa, jika perantau Minang mengenang atau mengingat kampung halaman dan Rumah Gadang mereka, menjadikan hati mereka hiba. Suasana hati hiba ini disebabkan karena perantau berada jauh di negeri orang dengan semua permasalahan dan tantangan hidup yang dilaluinya, sehingga mengakibatkan semakin tingginya rasa cinta dan rindu terhadap ranah Minang.
Kecintaan dan kerinduan terhadap kampung halaman, yakni ranah Minangkabau berdampak pada kondisi imajinasi orangorang atau masyarakat Minangkabau. Kampung halaman seakan-akan hadir di pelupuk mata mereka (tabayang-bayang di ruang mato). Kondisi ini menyebabkan pemikiran dan ingatan melayang jauh menuju kampung halaman yang tercinta.

Berdasarkan paparan aspek kebahasaan lirik lagu Minangkabau di atas, dapat digambarkan bahwa perwujudan tindakan dan perilaku orang-orang atau masyarakat, terutama para perantau Minang didasari oleh nilainilai yang mereka yakini. Nilai-nilai tersebut adalah: (1) nilai-nilai kecintaan terhadap kampung halaman atau kecintaan pada ranah Minangkabau (ranah bundo), (2) menghormati figur penting seorang ibu (bundo), (3) menghargai benda-benda pusaka atau peninggalan zaman dahulu (rumah gadang), (4) kebersamaan dalam menjalani hidup di rumah gadang yang ditinggali oleh beberapa orang keluarga, (5) hemat dan antisipasi terhadap berbagai kemungkinan buruk.

Lagu berikutnya adalah Kampuang Nan Jauah di Mato yang terdiri dari tiga bait. Kalimat pertama menyatakan, "Kampuang nan jauah di mato". Secara leksikal, kalimat tersebut dapat diartikan sebagai sebuah ungkapan kecintaan masyarakat Minang yang berada di diperantauan atau di luar ranah Minang. Kampung atau ranah diartikan sebagai sebagai sebuah tempat lahir, tumbuh, dan berkembangnya masyarakat Minang. Kampung atau ranah Minang, secara geografis berada di wilayah bukit barisan.

Kecintaan masyarakat Minang terhadap kampung halaman yang dikelilingi gunung atau berada di wilayah bukit barisan tersebut juga memunculkan rasa kerinduan yang tinggi kepada teman-teman atau sanak saudara sewaktu kecil yang selalu menemani keseharian anak-anak atau generasi muda Minang, seperti yang tertuang dalam lirik lagu, "Den takana jo kawan-kawan lamo, sangkek basuliang-suliang”. Kata basuliang-suliang mengandung banyak arti, secara tertulis/harfiah mengandung arti bermain suling secara bersama-sama sedangkan secara tersirat atau arti kata atau makna lain menyatakan suasana bermain secara bersama-sama, berbagi bersama, dan kegiatan atau suasana tersebut sering dilakukan. 
Bait kedua terdiri dari empat kalimat lagu yang mengandung arti bahwa penduduk atau warga masyarakat yang mendiami ranah Minang berisikan orang-orang yang elok. Arti tersebut dinyatakan dengan lirik, "Panduduaknyo nan elok, nan suko bagotongroyong". Makna kata "elok" mengandung arti secara leksikal sebagai ramah-tamah, sopansantun, aman-damai, dan rasa toleran antar sesame penduduk atau warga yang mendiami ranah Minang, baik hubungan sesama orang Minang maupun hubungan orang minang dengan warga lain yang berbeda agama dan berbeda budaya.

Sikap ramah-tamah, sopan-santun, aman-damai, dan rasa toleran yang tinggi menjadi sarana ampuh untuk membangun wilayah Minangkabau dan akan terwujud dengan adanya kegiatan gotong royong. Kegiatan gotong royong yang dilakukan secara bersama mengandung konsekuensi psikologis untuk menanggung rasa sakit dan senang. Rasa sakit dan senang tersebut bukan merupakan sebuah kendala, akan tetapi menjadi sebuah motivasi bagi seluruh warga atau penduduk ranah Minang untuk menyelesaikan permasalahan dengan segala resikonya secara bersama-sama. Kondisi tersebut sering disebut sebagai kerjasama sesame warga. Hal ini dinyatkan dalam lirik yang mengatakan, "Sakik sanang samo-samo diraso".

Suasana ramah-tamah, sopan-santun, aman-damai, dan toleransi melahirkan kebersamaan (gotong royong) tersebut selalu dikenang dan dibanggakan oleh warga atau penduduk Minang. Suasana tersebut menjadi barometer dan pedoman bagi para perantau Minang untuk menjalani kehidupannya di rantau atau di negeri orang. Seperti yang dinyatakan dalam lirik, "Den takana jo kampuang".

Bait ketiga berisi kenangan masa lalu yang dilalui oleh masyarakat Minangkabau dari kecil hingga dewasa, baik kondisi geografis, maupun suasana ramah-tamah, sopansantun, toleran, dan kebersamaan yang terbentuk di ranah bundo atau kampong halaman secara psikologis memunculkan perasaan untuk selalu mengingat dan mengenang masamasa itu, apalagi kerinduan terhadap keluarga (ibu, ayah, dan kakak atau adik).

Kondisi tersebut selalu membayangbayangi orang Minang untuk secepatnya pulang ke kampung halaman Minangkabau, seperti yang dinyatakan dalam lirik, "Takana jo kampuang, induak, ayah, adiak sadonyo. Raso maimbau-imbau den pulang. Den takana jo kampuang".

Secara keseluruhan lirik lagu Kampuang nan Jauah di Mato menggambarkan tentang suasana kampung halaman yang aman, nyaman, damai, dan asri serta serta memiliki sikap ramah-tamah, sopan-santun, toleran, dan suka bekerjasama (bergotongroyong) mempengaruhi pola pikir dan keyakinan orang Minangkabau dan selalu memotivasi orang Minangkabau agar senantiasa mencintai, melihat, dan mengenang kampung halaman di mana mereka berada.

Berdasarkan paparan analisis hermeneutik di atas, dapat diidentifikasi beberapa nilai-nilai edukatif yang terkandung dalam lirik lagu Kampuang nan Jauah di Mato, yakni nilai-nilai: (1) cinta dan rindu kampung halaman (ranah Minang), (2) kedamaian dan keadilan, (3) sopan-santun, (4) toleran, dan (5) kebersamaan (gotong royong).

Aspek Musik

Pertama, melodi. Jarak nada (interval) yang terdapat dalam perjalanan melodi lagu Minangkabau terdiri dari (1) interval prime (berjarak nol nada/sama) sebanyak 8 buah, (2) interval seconde (berjarak $1 / 2$ atau 1 nada) sebanyak 42 buah, (3) interval ters (berjarak $1 \frac{1 / 2}{2}$ atau 2 nada) sebanyak 18 buah, dan (4) interval kwart (berjarak $2 \frac{1}{2}$ nada) sebanyak 2 buah.

Perjalanan melodi tersebut didominasi oleh penggunaan interval seconde yang dapat digolongkan pada gerak melodi melangkah. Gerak melangkah dalam perjalanan melodi lagu Minangkabau dapat dilihat dari potongan notasi melodi pada birama 5 sampai dengan birama 8 , birama 13 sampai dengan birama 16, birama 21 sampai dengan birama 24, birama 29 sampai dengan birama 32 .

Gerak melangkah tersebut merupakan salah satu karakteristik lagu Minangkabau, di samping itu terdapat gerak melodi khas yang dikenal dengan sebutan galitiak/garinyiak atau cengkok Minang. Galitiak/garinyiak atau cengkok Minang secara jelas dapat diidentifikasi pada saat seseorang menyanyikan atau memainkan melodi lagu dan juga dapat diidentifikasi melalui gerakan nada-nada atau potongan melodi yang terdapat pada partitur lagu. 
Galitiak atau cengkok lagu Minangkabau merupakan faktor penentu yang membedakan kekhasan lagu-lagu Minang dibanding lagu-lagu daerah lain dan sekaligus memberikan sentuhan dan nuansa khusus pada semua masyarakat atau para perantau Minangkabau. Apabila masyarakat dan perantau Minangkabau mendengar gerakan melodi atau galitiak Minang tersebut, tak ayal ingatan mereka langsung tertuju pada suasana di kampung halaman atau ranah Minangkabau, apalagi melodi tersebut berasal dari bunyi alat musik tradisional minangkabau, seperti bansi, saluang, talempong, dan rabab.

Gerak melodi melangkah turun yang menjadi kekhasan (galitiak atau cengkok) Minang menggambarkan suasana yang cenderung tenang, aman, tentram, damai, harmonis atau dengan kata lain pergerakan melodi lagu Minangkabau dapat ditafsirkan sebagai gerak melodi yang menggambarkan suasana alam Minangkabau yang diliputi oleh suasana ketenangan, keamanan, ketenteraman, kedamaian, dan keharmonisan.

Kedua, ekspresi. Kecenderungan penggunaan pola irama yang dimiliki lagu Minangkabau mengarah ke bentuk perpaduan pola irama Minang dengan pola irama modern.

Pola irama tersebut hampir mewarnai kekhasan musik Minang secara umum, terutama lagu-lagu Minang yang menggunakan tempo lambat dan sedang (Adagio 70 sampai 74). Pola irama lagu Minangkabau tergolong ke dalam irama yang melankolis (lagu-lagu yang menggambar suasana sedih, mendayudayu (ratok atau sendu, pilu), sehingga menggugah perasaan dan suasana hati masyarakat Minangkabau yang dilanda perasaan cinta dan rindu terhadap kampung halaman.

Perasaan cinta dan rindu masyarakat Minangkabau dan para perantau semakin menjadi-jadi jika lagu tersebut dimainkan dengan menggunakan atau memperdengarkan alat musik tradisional Minangkabau, seperti saluang (alat musik tiup yang terbuat dari bambu), bansi (alat musik tiup yang terbuat dari bambu dan mirip alat musik recorder), talempong (alat musik pukul yang terbuat dari logam), rabab (alat musik gesek yang dimainkan sambil duduk), dan gandang (gendang).

Bunyi alat-alat musik tradisional Minangkabau tersebut mampu menghipnotis dan membuai (meninabobokkan) pikiran dan perasaan masyarakat Minangkabau untuk selalu mengingat keindahan dan keelokan kampung halaman, ranah Minang. Suasana tersebut menjadi nilai-nilai yang berpengaruh kuat bagi masyarakat atau perantau Minangkabau, di samping sebagai alunan musik yang menghimbau atau memanggil perantau untuk pulang kampung, sekaligus sebagai penawar dan pengobat rasa rindu mereka di negeri orang.

Penggunaan pola irama khas Minangkabau, perjalanan melodi yang melankolis dengan nuansa yang sedikit maratok (sedih dan pilu), dinyanyikan dalam tempo (kecepatan lambat) yang seakan-akan maimbauimbau (memanggil-manggil), sehingga menambah semakin tingginya perasaan cinta rindu para perantau terhadap kampung halaman, yakni ranah Minangkabau tacinto.

Selain pola irama khas Minang dan tempo lagu yang berhubungan dengan perlambangan suasana kampung halaman yang tentang, tenteram, damai, adil, dan harmonis, elemen berikutnya adalah jangkauan nada (ambitus) yang terdapat pada lagu Minangkabau.

Ambitus lagu Minangkabau berjarak $11 / 2$ oktaf (sebelas nada) dan tergolong pada jangkauan nada yang pendek dan tidak terlalu susah untuk dinyanyikan, serta sangat berpengaruh terhadap ekspresi seseorang ketika menyanyikan lagu. Jangakauan nada tersebut menggambarkan bahwa lagu Minangkabau merupakan lagu sederhana yang mudah diingat atau dihafalkan, sehingga memudahkan seseorang dalam proses pengekspresiannya. Hal ini sangat berkaitan dengan faktor kebertahanan dan dan kepopuleran lagu $\mathrm{Mi}$ nangkabau sampai dewasa ini.

Kondisi ini menandakan bahwa lagu tersebut disukai dan diminati oleh para pendengar atau penikmat lagu, serta nasehat serta pesan-pesan yang disampaikan berupa nilainilai kecintaan dan kerinduan terhadap ranah Minang semestinya masih dijadikan sebagai pedoman bagi masyarakat Minangkabau dalam menjaga dan melahirkan tindakan dan perilaku atau sikap yang sesuai menurut norma atau aturan adat budaya Minangkabau.

Aspek musik lagu Kampuang nan Jauah di Mato dapat dilihat dari perjalanan melodi lagu. Unsur melodi lagu Kampuang nan Jauah di Mato mengikuti aturan tangga nada modern, seperti aturan yang berlaku 
untuk unsur-unsur melodi lagu-lagu Minang yang lain, yakni menggunakan tangga nada diatonis.

Pergerakan melodi lagu Kampuang nan Jauah di Mato menggunakan empat jenis interval, yakni (1) interval prime sebanyak 13 buah, (2) interval seconde sebanyak 33 buah, (3) interval ters sebanyak 36 buah, dan interval kwart sebanyak 9 buah. Pergerakan melodi tersebut didominasi oleh penggunaan jarak nada (interval) seconde (berjarak $1 / 2$ atau 1 nada) dan interval ters (berjarak $1 \frac{1}{1 / 2}$ atau 2 nada).

Pergerakan melodi lagu dapat dikategorikan pada gerak melompat yang ditandai dengan dominasi penggunaan interval ters dan kwart yang berjumlah sebanyak 45 buah, sedangkan interval yang dapat dikategorikan sebagai gerak melodi melangkah (menggunakan interval seconde) hanya berjumlah 33 buah.

Dominasi gerak melodi melompat memberikan tingkat kesulitan tersendiri atau relatif agak sukar ketika dinyanyikan, akan tetapi gerak melodi melompat yang terdapat pada pergerakan melodi lagu Kampuang nan Jauah di Mato masih tergolong interval dengan jangkauan nada (ambitus) yang relatif pendek, yakni nada terendah adalah nada B dan nada tertinggi $\dot{C}$ atau dengan kata lain, jangkauan nada lagu tersebut hanya satu oktaf. Kondisi ini secara keseluruhan dapat dikatakan bahwa lagu Kampuang nan Jauah di Mato dapat dinyanyikan dengan mudah.

Gerak melodi melompat yang relatif agak sukar digunakan pada birama 3 sampai 4 atau birama 11 sampai 12 , atau birama 5 sampai 6 atau birama 13 sampai 14 .

Perjalanan melodi lagu Kampuang nan Jauah di Mato tidak terlepas dari galitiak (cengkok) Minang, baik yang terlihat atau tertulis dalam notasi musik maupun ornamen lain yang tidak dituliskan akan tetapi terlihat ketika melodi tersebut dinyanyikan. Galitiak Minang secara tertulis dapat dilihat pada birama 8 sampai 9 atau birama 23 sampai 24 .

Galitiak secara tertulis di atas ditandai dengan nuansa pergerakan melodi yang cenderung membentuk alunan-alunan dengan pengulangan nada-nada yang sama, selain itu menggunakan simbol legatura (garis melengkung) yang melahirkan nuansa melodi dan proses menyanyikan lirik lagu yang terkesan ditarik-tarik. Suasana alunan-alunan dengan pengulangan nada-nada yang sama dan proses menyanyikan lagu yang terkesan ditarik-tarik menjadikan pergerakan melodi sebagai salah satu karakteristik atau galitiak lagu-lagu Minang.

Kedua, ekspresi. Unsur ekspresi pada lagu Kampuang nan Jauah di Mato mengacu pada tiga komponen: pola irama Minang yang terdapat dalam iringan musik lagu Kampuang nan Jauah di Mato apabila ditinjau dari berbagai versi lagu yang sudah beredar cenderung merupakan perpaduan antara pola irama latin (cha cha cha) dengan pola irama Joget (melayu). Perpaduan pola irama tersebut melahirkan pola irama yang memperlihatkan nuansa Minangkabau, terutama pola irama lagu Kampuang nan Jauah di Mato yang dipopulerkan oleh penyanyi cilik Chiquita Meydi.

Tempo yang terdapat pada lagu Kampuang nan Jauah di Mato menggunakan tempo cepat (Allegretto 170). Perpaduan pola irama latin dengan pola irama joget (Melayu) dan kekhasan pola irama Minang yang dibawakan dengan tempo cepat melahirkan nuansa lagu yang bersemangat, riang, dan gembira. Tingkat kesulitan yang relatif mudah untuk dinyanyikan, lirik lagu yang mudah diingat atau dihafal, dan suasana riang menjadikan lagu Kampuang nan Jauah di Mato banyak dikenal oleh masyarakat, sehingga menjadikan lagu tersebut populer dan terkenal ke berbagai pelosok nusantara, serta ke manca negara.

Warna musik (timbre) yang terdapat pada lagu Kampuang nan Jauah di Mato dilahirkan melalui penggabungan alat musik tradisional Minangkabau dengan alat-alat musik modern. Alat-alat musik tersebut terdiri dari alat musik talempong atau alat musik yang menyerupai bunyi talempong yang dihasilkan dari bunyi keyboard (orgen), gandang atau congas, dan drum set, serta alat-alat musik pengiring lainnya seperti gitar elektrik dan bass elektrik. Perpaduan alat-alat musik tradisional Minang dengan alat-alat musik modern tersebut melahirkan iringan musik yang menambah semaraknya warna warna musik Minang tanpa meninggalkan ciri khas Minangnya.

Selain pola irama khas Minang dan tempo lagu yang berhubungan dengan perlambangan suasana kampung halaman yang tentang, tenteram, damai, adil, dan harmonis, 
elemen berikutnya adalah jangkauan nada (ambitus) yang terdapat pada lagu Kampuang nan Jauah di Mato.

Ambitus lagu Kampuang nan Jauah di Mato berjarak 1 oktaf lebih (sembilan nada) dan tergolong pada jangkauan nada yang pendek dan tidak terlalu susah untuk dinyanyikan, serta sangat berpengaruh terhadap ekspresi seseorang ketika menyanyikan lagu tersebut. Jangakauan nada tersebut menggambarkan bahwa lagu Kampuang nan Jauah di Mato merupakan lagu sederhana yang mudah diingat atau dihafalkan, sehingga memudahkan seseorang dalam proses pengekspresiannya. Hal ini sangat berkaitan dengan faktor kebertahanan dan dan kepopuleran lagu Kampuang nan Jauah di Mato sampai dewasa ini.

\section{Aspek Psikologi}

Ditinjau dari aspek psikologi, lirik dan musik lagu Minangkabau menggambarkan bahwa secara kejiwaan orang-orang atau masyarakat dan perantau Minang memiliki hubungan timbal-balik yang sangat erat, baik terhadap suasana alam Minangkabau dan suasana rumah gadangnya maupun suasana kehidupan orang-orang atau masyarakat $\mathrm{Mi}$ nang ketika berada di ranah bundo atau kampung halaman, apalagi ketika mereka berada jauh di negeri orang (di luar Minangkabau).

Kondisi tersebut menggugah suasana kejiwaan dan pemikiran mereka, dan pada akhirnya dapat memengaruhi tindakan dan perilkau yang memunculkan rasa hiba yang mendalam dan kerinduan yang tinggi untuk segera pulang ke kampung halaman. Bagi orang-orang atau masyarakat Minangkabau yang belum bisa pulang dikarenakan berbagai alasan yang rumit, melampiaskan kehibaan dan kerinduan terahadap suasana kampuang halaman, bundo kanduang, dan rumah gadang dengan mendengarkan dan melihat rekaman Video Compact Disk (VCD) lagu-lagu Minang.

Suasana emosional yang dihadirkan pencipta lagu adalah rasa rindu dan cinta terhadap keindahan dan keelokan kampuang halaman, yakni ranah Minangkabau. Pencipta lagu ingin membangkitkan rasa atau memberikan stimulasi suasana emosional orangorang Minang agar senantiasa mencintai dan merindukan kampung halamannya.
Aspek psikologi lagu Kampuang nan Jauah di Mato melambangkan suasana kecintaan dan kerinduan terhadap kampung halaman dihadirkan dan dikomunikasikan dengan stimulasi berbagai suasana emosional, seperti: (1) suasana keindahan alam Minangkabau yang berada jauh dari lokasi masyarakat Minang berada atau jauh dari rantau, (2) kampung halaman dikelilingi gunung dan bukit-bukit, (3) suasana sekampung-sepermainan (sangkek basuliang-suliang) dengan teman-teman sebaya, (4) suasana senasibsepenanggungan, kebersamaan, dan gotongroyong, (5) suasana keramah-tamahan dan keelokan perilaku masyarakat Minang, dan (6) suasana kekeluargaan.

\section{Aspek Sosiokultural}

Secara sosial, lirik dan musik lagu Minangkabau menggambarkan kondisi ikatan yang kuat dalam payung garis keturunan matrilineal. Hal ini memberikan kontribusi untuk mementingkan tanah kelahiran yang merupakan warisan atau pusaka bundo yang tetap terjaga dari zaman dahulu sampai sekarang, sehingga mereka selalu menghormati ibu (bundo) dengan cara mengenang dan mengingat-ingat ranah Minang dan suasana kehidupan di kampung halaman.

Hubungan kekerabatan sosial tersebut menjadi tali perekat antara perantau dengan masyarakat atau orang-orang yang berada di kampung halaman, terutama hubungan yang erat dengan sosok seorang ibu (bundo). Perantau yang tidak bisa pulang ke kampung halaman tidak tinggal diam, pada zaman sekarang mereka berinteraksi dengan menggunakan kecanggihan teknologi dan informasi. Mereka melakukan kontak dengan orangorang terdekat yang berada di kampuang halaman (Minangkabau) dengan menggunakan media sosial (medsos), seperti: twitter, facebook, whatsapp, blackberry mesengger. Hal itu mereka lakukan karena faktor ikatan sosial yang erat antara keluarga atau masyarakat yang berada di kampung halaman dengan perantau yang jauh di begeri orang.

Hubungan dan interaksi sosial tersebut merupakan sarana ampuh untuk mendekatkan hubungan antara perantau-perantau dengan keluarga dan masyarakat terdekat di kampuang halaman, selain itu ada beberapa kegiatan lain yang dilakukan oleh perantau, 
yakni melakukan interaksi sesama perantau yang senasib untuk mengadakan kegiatan berkumpul di rantau sambil mengenang atau membicarakan kondisi yang terjadi di kampung halaman, seperti kenangan semasa kecil, remaja, atau peristiwa-peristiwa lain yang erat kaitannya dengan kampung halaman.

Secara kultur, lagu Minangkabau tidak terlepas dari nilai-nilai yang mendasari keyakinan, pemikiran, ataupun ide-ide yang melahirkan tindakan dan perilaku manusia, serta benda-benda hasil ciptaan atau karya manusia atau dengan kata lain nilai-nilai tersebut ikut mempengaruhi pembentukan peradaban atau kebudayaan manusia. Ditinjau dari aspek kultur atau budaya, lirik dan musik lagu Minangkabau merupakan gambaran pemikiran atau ide pencipta lagu untuk menghadirkan suasana budaya Minangkabau dalam sebuah karya lagu. Lagu tersebut melambangkan kecintaan dan kedekatan perasaan orang Minang terhadap kampung halaman mereka yakni ranah Minang dan Rumah Gadang sebagai bentuk artifak yang melambangkan bentuk khas rumah yang sekaligus mewakili keberadaan masyarakat di Minangkabau.

Aspek sosiokultural pada lagu Kampuang nan Jauah di Mato secara umum dpat digambarkan bahwa sumber ide dan topik yang dijadikan sebagai sarana dalam menciptakan lagu berpedoman pada dua hal, yakni: memanfaatkan kondisi alam dan realitas sosial budaya yang terjadi, berlaku, dan berkembang di lingkungan masyarakat Minangkabau. (1) kondisi alam kampung halaman yang jauh di mata dan dikelilingi oleh gunung atau perbukitan, (2) realitas sosial budaya, seperti: mengingat teman-teman lama sewaktu kecil, masyarakat yang aman dan damai, suka bergotong royong, dan memiliki rasa kekeluargaan yang tinggi.

Kondisi alam dan realitas sosial budaya yang terungkap dalam lagu tersebut memberikan gambaran bahwa keduanya memiliki keterkaitan yang sangat erat dalam menentukan kondisi sosial budaya masyarakat. Faktor yang berasal dari kondisi alam ikut memengaruhi realitas sosial budaya yang muncul, atau dengan kata lain dapat dikemukakan bahwa kondisi alam pedesaan yang masih menganut satu identitas budaya (monocultural) serta menggunakan norma atau aturan dan nilai-nilai yang sama sangat memungkinkan untuk melahirkan realitas masya- rakat yang aman dan damai, suka bergotongroyong, dan memiliki rasa kekeluargaan yang tinggi.

Kondisi realitas sosial yang terjadi, berlaku, dan berkembang di lingkungan kampuang halaman Minangkabau tersebut secara tidak langsung turut memengaruhi pola pikir, tindakan dan perilaku masyarakat Minangkabau dengan munculnya perasaan ingat terhadap kampung halaman, bahkan diibaratkan dengan kondisi alam dan kondisi sosiokultural yang memangil-manggil ketika masyarakat Minangkabau berada jauh dari kampung halaman untuk segera pulang.

\section{Aspek Pendidikan dan Nilai-nilai Edukatif}

Berdasarkan paparan interpretasi hermeneutik yang dilihat dari aspek kebahasaan, musik, psikologi, dan sosiokultural terhadap lagu Minangkabau yang telah dikemukakan sebelumnya dapat ditafsirkan bahwa masyarakat Minangkabau, baik yang berada di kampung halaman maupun yang merantau ke negeri orang di seantero pelosok dunia merasakan kerinduan dan kecintaannya terhadap ranah Minangkabau apalagi Rumah Gadang yang menjadi ikon atau lambang budaya Minangkabau.

Rasa rindu dan cinta tersebut muncul karena masyarakat Minangkabau telah disuguhkan dengan adat budaya Minangkabau semenjak mereka lahir sampai menjelang ajal menjemput. Adat budaya tersebut sudah ditanamkan dan dilaksanakan di manapun mereka berada. Nilai-nilai kerinduan dan kecintaan terhadap ranah Minangkabau membuat mereka rela untuk melakukan tindakan dan perilaku yang membutuhkan pengorbanan untuk mewujudkannya.

kabau, yaitu:

Nilai-nilai edukatif lagu Minang-

Pertama, cinto ranah Minang; nilainilai tersebut merupakan interpretasi terhadap kalimat "Minangkabau tanah nan den cinto", "Jikok den kana hati den taibo", dan "Tabayang-bayang di ruang mato".

Kedua, waspada; nilai-nilai tersebut merupakan interpretasi dari kalimat "Rangkiang baririk di halamannyo". Masyarakat Minangkabau terbiasa selalu merencanakan dan mempersiapkan segala sesuatu kebutuhan hidup terutama pangan (padi) yang di simpan 
dalam lumbung (rangkiang) yang terletak di halaman rumah gadang.

Ketiga, keteguhan hati; nilai-nilai tersebut merupakan interpretasi dari keteguhan hati yang dijalani seorang perantau Minang dalam memperjuangkan hidup, beradaptasi dengan suasana baru, kerja keras agar dapat bertahan hidup dan menyingkirkan segala macam rintangan di negeri orang. Nilai-nilai tersebut merupakan interpretasi dari kalimat "Jikok den kana hati den taibo", dan "Tabayang-bayang di ruang mato".

Keempat, kesatuan dan kebersamaan; nilai-nilai tersebut merupakan interpretasi dari kalimat "Pusako bundo nan dahulunyo", "Rumah Gadang nan sambilan ruang". Sejak zaman nenek moyang dahulu kala, orang Minang telah terbiasa hidup dengan kebersamaan, hal itu dibuktikan dengan keberadaan Rumah Gadang. Rumah gadang dihuni oleh beberapa keluarga dalam satu kaum, mereka hidup adil, rukun, dan damai.

Kelima, musyawarah dan mufakat; nilai-nilai tersebut juga tercermin dari kesatuan dan kebersamaan yang dilakukan di Rumah Gadang. Oleh karena banyaknya keluarga yang mendiami rumah gadang dan agar masingmasing keluarga tidak berbenturan satu sama lain, tentu ada aturan adat yang menjaganya. Aturan tersebut dilahirkan dari proses musyawarah untuk mendapatkan kata mufakat.

Keenam, adil dan damai; merupakan nilai-nilai yang diinterpretasi dari suasana demokrasi yang terjalin di Rumah Gadang. Keputusan yang diambil oleh para datuk (penghulu) atau mamak (paman) tidak berat sebelah akan tetapi adil untuk keseluruhan penghuni rumah gadang sedangkan nilai-nilai kedamaian diinterpretasi dari pelaksanaan semua keputusan yang diambil dengan jalan musyarawah untuk mufakat yang dapat diterima oleh semua anggota kaum berada di Rumah Gadang.

Ketujuh, disiplin; merupakan nilainilai dasar yang diinterpretasi dari ketaatan dan kepatuhan masyarakat dan perantau Minang dalam menjalankan aturan atau normanorma adat dan watak orang Minangkabau. Di pihak lain, disiplin merupakan nilai-nilai yang diinterpretasi dari ketaatan dan kepatuhan para pemain musik dan penyanyi dalam mengindahkan segala macam aturan atau norma-norma yang terdapat dalam sebuah penampilan musik/lagu. Nilai-nilai ditaati dan diikuti oleh pemain musik dan penyanyi, sehingga melahirkan harmoni dan keindahan dalam sebuah penampilan musik/lagu, atau dengan kata lain nilai-nilai disiplin menjadi dasar untuk melahirkan sebuah karya musik/ lagu yang memiliki keindahan.

Nilai-nilai lagu Minangkabau merupakan nilai-nilai yang sangat penting dan bermanfaat bagi pendidikan. Nilai-nilai tersebut memberikan tuntunan, nasehat, didikan dalam rangka membangun karakter peserta didik, baik ketika berada di sekolah maupun di keluarga.

Nilai-nilai edukatif lagu Kampuang nan Jauah di Mato terlihat dari upaya menghadirkan kondisi alam dan realitas sosiokultural oleh seniman atau pencipta dalam sebuah karya lagu yang mengisyaratkan beberapa nasehat atau pesan-pesan yang mengedukasi masyarakat Minang dan hal tersebut merupakan nilai-nilai. Nilai-nilai tersebut, yakni:

Pertama, Ketuhanan; merupakan penafsiran dari kondisi alam yang menjadi latar belakang daerah Minangkabau, yakni daerah yang dikelilingi oleh gunung-gunung atau perbukitan. Alam dengan segala bentuk dan isinya merupakan ciptaan Allah SWT, dengan demikian kondisi alam tersebut merupakan nilai-nilai yang bersumber dari kekuasaan Allah SWT (Tuhan), salah satunya tertuang dalam lirik kampuang nan jauah di mato, gunuang sansai bakuliliang.

Kedua, persaudaraan; merupakan hasil penafsiran dari faktor alam dan kondisi realitas sosial budaya yang menunjukkan bahwa individu atau masyarakat Minangkabau yang telah pergi dari daerahnya (merantau) dalam waktu yang lama masih tetap ingat teman-teman lama, teman-teman sepermainan sewaktu kecil. Nilai-nilai persaudaraan tersebut salah satunya tercantum dalam lirik den takana jo kawan-kawan lamo, sangkek basuliang-suliang.

Ketiga, aman dan damai; merupakan penafsiran terhadap kondisi alam dan realitas sosial yang menggambarkan bahwa masyarakat yang mendiami daerah Minangkabau adalah masyarakat yang baik (elok). Masyarakat yang elok dapat ditafsirkan sebagai masyarakat yang diliputi suasana keramah-tamahan, keadilan, dan ketenteraman yang ditunjukkan dengan saling menjaga sikap toleran dan kebersamaan. Nilai-nilai tersebut tercantum dalam lirik panduduaknyo nan elok. 
Keempat, gotong-royong; merupakan penafsiran dari kondisi masyarakat yang saling menjaga sikap toleran dan memiliki kepedulian yang tinggi antar sesama, sehingga dalam menyelesaikan suatu pekerjaan dan mencapai suatu tujuan tertentu cenderung dilaksanakan dengan cara bergotong-royong. Nilai-nilai gotong-royong tercantum dalam lirik nan suko bagotong-royong.

Kelima, kekeluargaan; merupakan penafsiran dari suasana keakraban, persaudaraan, dan kepedulian yang tinggi antarsesama warga, baik kegembiraan dan kesedihan yang terjadi di rumah tangga maupun di lingkungan masyarakat. Nilai-nilai kekeluargaan tercantum dalam lirik sakik-sanang samo-samo diraso.

Keenam, kesatuan budaya; merupakan penafsiran dari keseluruhan realitas sosial yang terjadi, berlaku, dan berkembang di lingkungan budaya masyarakat Minangkabau yang muncul dari rasa cinta dan rindu terhadap suasana kehidupan masyarakat Minangkabau yang diliputi oleh nilai-nilai Ketuhanan, persaudaraan, gotong-royong, dan kekeluargaan. Perpaduan nilai-nilai tersebut melahirkan masyarakat yang bersatu, damai, dan tenteram di bawah naungan norma atau aturan adat budaya Minangkabau.

Hasil analisis hermeneutik terhadap kandungan nilai-nilai edukatif kedua lagu minang di atas, dapat diuraikan bahwa lagu Minangkabau memiliki 7 (tujuh) nilai-nilai edukatif dan lagu Kampuang nan Jauah di Mato memiliki 6 (enam) nilai-nilai edukatif. Kedua lagu tersebut memiliki 13 (tiga belas) nilai-nilai edukatif. Setelah dilakukan analisis untuk melihat kesamaan dan perbedaan arti masing-maing nilai-nilai tersebut, baik dari segi leksikal maupun arti secara denotatif dan konotatif, ditemukan 9 (sembilan) nilai-nilai eduaktif.

\section{SIMPULAN}

Penafisiran hermeneutik terhadap Lagu Minangkabau dan Kampuang nan Jauah di Mato menemukan bahwa kedua lagu tersebut mengandung 9 (sembilan) nilai-nilai edukatif, yaitu: (1) Ketuhanan (syarak atau agamo), (2) kecintaan terhadap ranah Minang, (3) persaudaraan dan gotong-royong, (4) kesatuan dan kebersamaan, (5) musyawarah dan mufakat, (6) adil dan damai, (7) keteguhan hati, (8) waspada, dan (9) disiplin. Nilai-nilai edukatif lagu-lagu Minang tersebut dijadikan sebagai pedoman dalam mengarahkan pikiran, tindakan, dan perilaku peserta didik, sehingga dapat diwujudkan peserta didik yang beradat, beradab, berkarakter.

\section{Saran}

Mengingat pentingnya upaya pembudayaan nilai-nilai edukatif lagu-lagu Minang dalam rangka membangun karakter peserta didik di lingkungan pendidikan dasar Kota Padang, disarankan kepada:

Kepala sekolah agar membudayakan nilai-nilai edukatif lagu-lagu Minang, baik dalam kegiatan akademis maupun non-akademis, mampu memberikan contoh sikap tauladan yang sesuai menurut adat budaya Minangkabau, mengapresiasi serta menyediakan sarana pendukung terhadap kegiatan sekolah yang berhubungan dengan penampilan, baik kegiatan yang dilaksanakan dalam pembelajaran (seni musik) maupun kegiatan ekstrakurikuler, serta mengikutsertakan peserta didik dalam kegiatan lomba lagu Minang.

Guru-guru, khususnya guru seni musik dan Budaya Alam Minangkabau (BAM) agar selalu memberikan pembelajaran tentang lagu-lagu Minang yang diikuti dengan mengeksplorasi dan membudayakan nilai-nilai edukatif yang terkandung di dalamnya.

Orang tua/Masyarakat agar senantiasa membudayakan bahasa Minangkabau ketika berkomunikasi dengan peserta didik di lingkungan rumah dan masyarakat, mampu memberikan contoh sikap tauladan yang mencerminkan nilai-nilai adat budaya Minangkabau, dan menyediakan sarana pendukung baik dalam bentuk mendengarkan lagu-lagu Minang ataupun memberikan kesempatan kepada peserta didik untuk mengikuti lomba lagulagu Minang.

Pemerintah dalam hal ini Dinas Pendidikan Kota Padang agar senantiasa mendukung dan mengapresiasi pembudayaan nilainilai edukatif lagu-lagu Minang dalam bentuk kebijakan-kebijakan dalam membangun karakter peserta didik.

\section{DAFTAR PUSTAKA}

Amir, M.S. (2011). Adat Minangkabau: Pola hidup dan tujuan hidup orang Minang. Jakarta: Citra Harta Prima

Arthur, J. \& Baely, R. (2002). School and community: The communitarian agenda in education. London, New York: 
Falmer Press, Taylor and Francis Group

Astuti, K.S. (2010, Juni 11-13). Shaping morality through music learning in formal schools in Indonesia: An evaluation study. Artikel dipublikasikan pada Asia Pasific Network for Moral Education 5th dalam Annual Conference Interdisciplinary Moral Education in Asia's Globalising Societies; Concept and Practices. Japan: Nagasaki University

Barendregt, B. (2002). The sound of 'longing for home': Redefining a sense of community through Minang popular music. Bijdragen tot de Taal-, Landen Volkenkunde, 158, No: 3, 411-450: Leiden University

Berkowitz, M.W. (2002). The science of character education. Dalam Damon, William (Ed). Bringing a new era in character education (pp. 43-63). Stanford University: Hoover Institution Press

Budiman, S. (2011, Maret 6). Lagu Minang Baru Muncul di Era 70-an. Padang: Harian Haluan Padang

Darwis. (2005, November 28). Tafsir pantun Minang I. Artikel 655. Diambil pada tanggal 22 Januari 2012, dari http://www.cimbuak.net/content/view /655/5/1/1/

Dewantara, K.H. (1977). Pendidikan: Bagian I. Yogyakarta: Majelis Luhur Persatuan Taman Siswa.

Fithri, W. (2013). Mau kemana Minangkabau? Analisis hermeneutika atas perdebatan Islam dan adat Minangkabau. Yogyakarta: Gre Publishing

Fraser, J. (2011). Pop song as custom: Weddings, ethnicity, and enterpreneurs in West Sumatra. Jurnal Ethnomusicology Sping/Summer, Vol. 55, No. 2, p. 200-228. Ohio: Society for Ethnomusicology

Hajizar. (2012, Maret 13). Lagu padang dulu dan kini. Artikel. Diambil pada tanggal 3 Maret 2014, dari http://albiouna.com/umum/lagupadang-dulu-dan-kini
Hakimy, I. (2004). Rangkaian mustika adat basandi syarak di Minangkabau. Bandung: Rosda Karya

Jakoubek, R.E. (2005). Martin Luther King: Civil rights leader. New York: Infobase Publishing

Lickona, T. (1991). Educating for character: how our schools can teach respect and responsibility. New York, Toronto, London, Sydney, Aucland: Bantam Books

Naim, M. (2003). Konflik dan konsensus antara adat dan syara' di Minangkabau dalam reaktualisasi Adat Basandi Syara', Syara' Basandi Kitabullah. Padang: PPIM

Riadi. (2013). Opini: Puluhan pelajar tersandung kasus. Padang: Harian Pagi Padang Ekspres. Diambil pada tanggal 14 April 2014 dari http://padangekspres.co.id/?news=beri ta\&id=43089

Reno, P. (2012, Oktober 1). Iptek maju, budaya Minang terancam. Padang: Harian Padang Ekspres. Diambil pada tanggal 15 Juni 2014 dari http://www.padangekspres.co.id/m/be rita.php?id=35403

Sairin, S. (2004). "Minangkabau yang gelisah" dalam Minangkabau yang gelisah. Bandung: CV. Lubuk Agung

Sayuti, M. (2012). Lembaga Kerapatan Adat Alam Minangkabau (LKAAM) nilai mata pelajaran Budaya Alam Minangkabau (BAM) belum efektif. Artikel. Diambil pada tanggal 4 Februari 2014, dari http://www.antarasumbar.com/berita/ provinsi/d/1/208885/lkaam-sumbar

Suratman. (1987). Pokok-pokok ketamansiswaan. Yogyakarta: Majelis Luhur Persatuan Taman Siswa.

Tilaar, H.A.R. (2010). Paradigma baru pendidikan nasional. Jakarta: Rineka Cipta

Wachid, A. (2006). Hermeneutika sebagai sistem interpretasi Paul Recoeur dalam memahami teks-teks seni. Diterbitkan dalam Jurnal Imaji, Vol. 4, No. 2, Agustus 2006: 210-221

Zainuddin, M. (2010). Pelestarian dan eksistensi dinamis adat Minangkabau. Yogyakarta: Ombak. 